\title{
Fred Gentili, MD, FRCSC (1947-2022): Say it loud, say it clear
}

\author{
Jacques J. Morcos ${ }^{1}$
}

Received: 25 January 2022 / Accepted: 26 January 2022 / Published online: 4 February 2022

(c) The Author(s), under exclusive licence to Springer-Verlag GmbH Austria, part of Springer Nature 2022

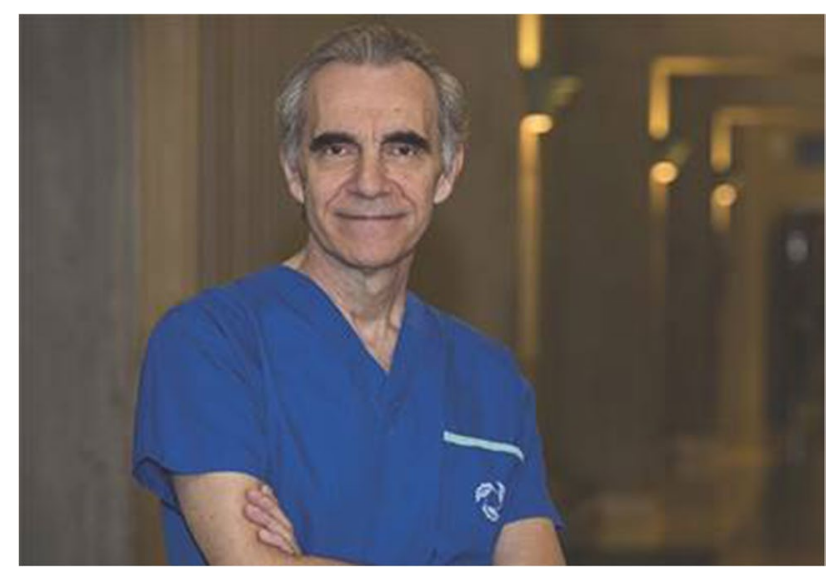

In early June 2021, I-and many others-received a very sad email from Dr Gelareh Zadeh, Dan Chair and Professor of Neurosurgery at the University of Toronto. She was announcing to the world that her mentor and partner, skull base neurosurgeon extraordinaire, teacher of legions, friend to many, one of the most loveable figures in neurosurgery, Fred Gentili, had just been diagnosed with a most aggressive multifocal Glioblastoma and was due to undergo surgery in a few days. Fred himself had asked for the news to be disseminated. He had lived his life in the most open, embracing and transparent of fashions; true to self, there was no reason for him to become secretive when the terminal illness paid him visit. Lesser men would have crumbled, but not him. Lesser men would have retreated in their dead shell, yet he was poised to spring spectacularly out of his, which was anything but dead.

Jacques J. Morcos

jmorcos@med.miami.edu

1 Department of Neurological Surgery, Cerebrovascular and Skull Base Surgery, University of Miami, FL, Miami, USA
I called him instantly. He told me how on the prior Friday he was in the early stages of operating on an acoustic neuroma when he and his assisting resident noticed that the fingers of his left hand were rather clumsy. These elegant, graceful and nimble fingers that had healed thousands of patients before, these fingers that in a pre-digital life probably slotted thousands of Kodak slides into hundreds of carousels, these fingers that had since mastered the suction, the forceps and the endoscope, had clicked on so many keyboards during so many lectures in so many countries; these fingers that had lovingly patted the backs of so many students, trainees, peers and patients, that had held glasses of Italian wine, that had turned pages of neurosurgical journals and biographical books, those very same fingers were now quitting. Passion drove them, skill perfected them, experience tempered them, but now cancer claimed them. He told me how he went down to the Emergency Room to have a brain scan. Perhaps he was having a small stroke. There, standing with his team, looking at his own scan, he must have lived a few minutes that I can only presume shook his being to its core. In an ultimate act of self-realization and auto-analysis, the magnificent brain discovered it was diseased. Life instantly changed. During those moments, the heart of the man likely paused for a prolonged reflection; yet the mind and habits of the true professional kept going, unabated. Let's discuss the image findings with the residents standing by; after all, is it not just another case in a day's work? Who else is a better master at metacognition than a neurosurgical master? Who else can better dissociate cancer from self, tragedy from hope, self-pity from outward exaltation, reality from spirituality, mindlessness from mindfulness. Who else can, when the chips are down, proudly and defiantly scream William Henley's timeless words from Invictus:

It matters not how strait the gate

How charged with punishments the scroll

I am the master of my fate

I am the captain of my soul 
Fred can, and it surprises no one. And who does he choose to be his surgeon? In an ultimate display of supreme and unfettered authenticity, and a clear demonstration that his entire life, with all its beliefs and convictions, had been an open journey unpolluted by hypocrisy, deceit, secrecy, or pretense, a life marked by walking the walk, believing in what you preach and what you do, it was so natural to him to put this very life in the hands of one of his best and trusted trainees, Gelareh Zadeh, who happens to be, undoubtedly in large measure due to his own influence, one of the most accomplished neurooncological surgeons in the world.

He valiantly faced, embraced, and transcended his dreadful diagnosis. He certainly was not alone. There was his rock of a wife, Gina, constantly at his side, for better and for worse. They had been married for 15 years. He rarely travelled without her to any neurosurgical gathering. I used to kid with Fred and tell him: "You know, we all came for you, but stayed because of Gina." The diagnosis of GBM certainly brought hiccups, tears, and shattered dreams for this remarkably compatible couple. But there was also, and above all, the incredible realization by Fred himself that he had had a global impact, beyond anything he had imagined. On the evening of his surgery, there were no less than 50 video messages from well-wishing neurosurgeons from around the globe, pouring into Gina's phone. All were asked to begin the message with the phrase: "Say it loud, say it clear," as an homage to the lyrics of Fred's favorite song "The Living Years" by "Mike and the Mechanics." From June 2021, until the day he passed, January 15, 2022, Fred lived in the constant amazement that he had, seemingly inadvertently-in their own words- - "changed the lives" of so many trainees that had been influenced by his persona and mentorship. In an ultimate manifestation of noble humility, he repeatedly and genuinely expressed that he was truly oblivious to the impact he had made. It is precisely because of this that he conveyed perhaps his greatest regret and warned us to learn from his mistake. What had he learned? That love is undervalued and under-communicated. If you feel it, say it. "Say it loud, say it clear." Do not let your stoic and reserved nature get in the way of expressing empathy, appreciation, and genuine emotions. Let the people you love know it. Do not wait until they are ill to tell them. Life would have passed you and them by. And Fred was not talking about romantic love, or at least not only that. He was talking about those more complex and certainly more interesting forms of human bonding: friendship, gratitude, admiration. This newly realized joy of being loved and appreciated certainly softened somewhat the blow of his illness. After all, mortality is inevitable, but legacy is not. What he was leaving behind made it all worthwhile.

Fred Gentili was born in a small town in Italy of less than 4000 inhabitants, called Sarnano. Perhaps there lies the seed of his legendary humility. His family emigrated to Toronto when he was a child. He attended the University of Toronto for Medical School (MD 1972) and Neurosurgical Residency (1980). Enamorate with microsurgery, he completed clinical Fellowships with Alan Hudson in his own Program, as well as Gazi Yasargil in Zurich and Lyndsay Symon in London. He then returned home and practiced his neurosurgical craft, starting at the Toronto General Hospital in 1982 and ending as Professor in the Division of Neurosurgery, Krembil Brain Institute at Toronto Western Hospital, and the University of Toronto. Fred recognized very early on, and well ahead of the rest of the neurosurgical world, the necessity to build a coalition of subspecialty talents to best serve the surgical needs of patients with complex skull base tumors. So, with his head and neck surgeon friend and colleague Pat Gullane, he created the first of its kind interdisciplinary skull base center. Over the span of 40 years spent perfecting the art and science of skull base surgery, he has contributed seminal works to the literature, amassed numerous accolades and championed pioneering achievements. I will name just a few. $\mathrm{He}$ is a Founding Member of the Society of Neurovascular Surgery (1985) and the North American Skull Base Society (NASBS) (1988). In addition to garnering numerous awards in Teaching Excellence and Patient Care, he is a recipient of an Honorary Membership in the Italian Neurosurgical Society (2010), the Gold Medal of the University of Messina (2011), the College of Physicians and Surgeons of Ontario Council Award for clinical excellence in patient care, the Sir Charles Balance Memorial Medal from the British Skull Base Society, and for his most recent distinction in July 2021, the first ever World Federation of Skull Base Societies Gold Medal of Honor. Fred has the rare distinction too of holding two separate Academic Chairs: The Alan and Susan Hudson Chair in Neurooncology (2014-) and the Crean Hotson Chair in Skull Base Surgery (2016-). And as if these recognitions were not sufficient to convince the world of his special talents, he was also knighted in 2017 by no less than the President of Italy and so became "Cavaliere Gentili."

In as much as it brings me personal pleasure to recall what I already knew, to reminisce on how distinguished my dear friend was and to highlight his achievements for those who did not know him well, I already regret writing the paragraph above. If Fred was still among the living today, he would have read it and remarked:

\section{Jacques, why did you label me? Do not put a sticker on me: neurosurgeon, skull base surgeon or other. \\ These labels that we put on ourselves mean nothing. They peel off like dry leaves fall off an autumn tree.}

I have saved on my phone a special file. It is a video of him speaking extemporaneously via Zoom to the graduating class of neurosurgical residents at the University of Toronto in June 2021, less than a week following his surgery. Here is some of what he tells them: 
I have learned over the last 2 weeks who I really am. And you know, that Fred Gentili is a much better person than Fred Gentili the skull base surgeon. He is more thoughtful, kind, loving... It is through love that all bitterness becomes sweet; it is through love that all copper becomes gold; it is through love that all dregs become fine wine... And with all the worries and disappointments that we go through, it is Love that flings them away like the wind flings the shells off a sandy shore.

What a remarkable thing to realize and convey, as one ponders one's mortality. But who is this man really? I have known him for 20 years and have no doubt others who have known him even more closely or longer would be able to pay better homage to him and his memory. The man I know stands out from the neurosurgical crowd. I have known him through international neurosurgical meetings, hands on courses around the globe, and through common trainees that he has influenced and a small group of common friends that shared similar values and passions. We have debated the merits and pitfalls of endoscopic resection of anterior skull base meningiomas and numerous other topics. With our wives, we have enjoyed great dinners around the world and the most joyful and meaningful conversations. There is an unforgettable dinner which included another giant, Evandro de Oliveira, at L'Archeologia restaurant in Rome, that featured memorable exchanges about life and spirituality and that have stayed with us since.

During our long friendship, I have come up with only two criticisms of him. He is incapable of remembering or delivering a joke, and the only one he has ever memorized (the "elbow" joke) is almost never recounted correctly in spite of being short! I have also criticized him for the formatting of his slides during his lectures: too much text, all in capital letters, with busy font and color schemes that distract the audience. The rest of who he is makes for a remarkably special human being.

The surgical skill is legendary. He lives and breathes neurosurgery, perhaps to the detriment of other activities. The operating room is his temple, where a day is not complete if he has not tackled the most complex cases. Yet the zeal remains measured, and his clinical judgement is impeccable. He looks at each "case" as a human being. He is not after a postoperative trophy scan. He is after the perfect outcome, the perfect cure, the grateful smile. He will be thoughtful, he will analyze, he will do the right thing. The reasoning is shrewd and razor sharp. He is not eager to impress, but to serve. He is not in love with himself, with his skills, with his superior abilities, with the authority he projects. He routinely undermined them. He is in love instead with his vocation, his craft, the essential need to teach it and his desire to impact lives. He was too busy focusing on the impact he had on his patients to realize the impact he also had on his students.

The surgical passion was too overwhelming for one individual to contain. That's why he taught, frequently, with assiduity and infectious enthusiasm. A supreme educator, he loved the hands-on courses, for they are the rehearsal stage for the operating room. It is there that one could witness a sweet paradox. The mature and experienced practitioner had a child-like and insatiable pleasure in discovering new surgical tricks and new knowledge. But the most unusual paradox of his persona was the secret to his popularity. Stature, fame and accomplishments never ever eroded that constant yearning for honesty, that self-deprecating humility, that allembracing humanism, that deep sense of ethics and responsibility, that old-fashioned sensitivity to what is right, what is respectable, what is worthy, what is morally admirable; that loyalty to true friends, that absolute transparency of character, that all too rare gift of inspiring trustworthiness. Fred said what he meant, and always meant what he said. You learned from watching the Surgeon, you returned to listen to the Educator, and you never left out of admiration for the Man. That is why his appeal is universal.

There was a third paradox in his personality that constitutes the secret to his neurosurgical longevity. A character like his would be expected to remain dogmatic and entranched into old habits acquired through tough lessons. Remarkably, he was extremely open minded and, well into his $50 \mathrm{~s}$, became one of the early adopters of endonasal skull base endoscopy. Not afraid to learn new skill sets, it did not take him long to master them. An ethically driven innovator blessed with superlative surgical skills, whose character remained grounded and unincumbered by the usual frailties brought on by fame and adulation! If that is not the ultimate role model, I am not sure what is.

I do not know why humanity occasionally gets lucky and someone like Fred comes along. Gibran Khalil Gibran has stated that "Out of suffering have emerged the strongest souls; the most massive characters are seared with scars." I never appreciated any scars under Fred's massive character. His skill in concealing them must have been as refined as the sincerity with which he never let arrogance tarnish his talent. After all, he had lost not one, but two wives to cancer, Patricia and then Alice. He also lost a son, Ryan, as a stillborn. How remarkable that a life marred with such utter tragedies can still beget joy, infuse optimism, and inspire enthusiasm and that the deepest darkest valleys can still lead one to the highest and sunniest peaks. Whatever forged whom he became, we should be grateful for the soul that emerged. Countless patients were lucky and countless friends and trainees were blessed by his existence.

And so, in the early evening hours of Saturday January 15,2022 , a battle for survival was lost, and humanity 
became a little less lucky, talented, honest and humble. His wife Gina, his sons Michael and David, and his mother-inlaw Angela were at the bedside of a classic giant of neurosurgery when his soul peacefully went to a room next door. Skull base surgery is likely undergoing a revolution in some other world. But to those remaining in this world and cared about Fred, my consolation to you is to quote again Gibran:

When you part from a friend, you grieve not; for that which you love most in him may be clearer in his absence, as the mountain to the climber is clearer from the plain.

So dear Fred, I have now seen, for the first time, the mountain that still stands in Toronto. It is called your Legacy. I am looking right at it, all the way from the distant plains of South Florida. The view is crystal clear, and the sight is majestic. The mountain is mighty, composed partly of Canadian metamorphic rock, and partly of Italian marble, but $100 \%$ original, inimitable, and unassailable. The view from its top will be afforded to very few climbers, yet the summit will be visible from distant lands to many. And best of all, my friend, that mountain will never die.

I hope I was loud enough and clear enough. I will see you on the other side and you will let me know.

Publisher's Note Springer Nature remains neutral with regard to jurisdictional claims in published maps and institutional affiliations. 